\title{
Analysis of Conceptual Metaphors in Deutsche Welle Newspaper based on the Perspective of Linguistic Relativity
}

\author{
Novia Anjani Dewi \\ Universitas Pendidikan Indonesia \\ J1. Dr. Setiabudi No.229 Bandung, Indonesia \\ noviaadewi@upi.edu \\ Article History: Submitted on $10^{\text {th }}$ April 2021; Accepted on $14^{\text {th }}$ October 2021; \\ Published on 30 ${ }^{\text {th }}$ December 2021
}

\begin{abstract}
Generally, metaphor is a language style that is often used as a form of creativity in communicating. However, the wider scope of the use of metaphors has led to interference from other aspects, one of which is the cultural aspect. The cultural aspect is considered to play an important role in shaping the way each individual perceives something. To prove this perspective, this study aims to identify whether the use of metaphors can be influenced by culture when compared to the perspective of linguistic relativity. The object of this research was discourse text in Deutche Welle newspapers in Indonesian and German. The 5-Step Metaphor Analysis Method was used in this research. The results of the meaning analysis that has been done, show that there is a conceptual metaphor used that is influenced by the cultural aspect. This means that the use of metaphors based on the perspective of linguistic relativity is acceptable.
\end{abstract}

Keywords: conceptual metaphors, discourse analysis, linguistic relativity

\section{INTRODUCTION}

In terms of function, language is a means of communication. Cruse (in Pentopikalan, 2018) states that language is the ability for humans to communicate using certain types of signs and arrangement of several types of units. One of the specific signs referred to is the use of metaphors. In Kamus Besar Bahasa Indonesia (KBBI), metaphor is defined as a style of language or figure of speech, which functions to describe something by equating it with something else. This is in line with the view of Lakoff \& Johnsen (2003) which states that metaphors reflect what we think, what we experience, and 
what we do in everyday life. The purpose of this reflection means that in communicating we do not have to always express something with the real meaning, but we can analogize this expression with other elements in the form of words that are considered to be equivalent to that meaning. One example of using metaphors according to Kövecses (2000) is an expression of 'Love is fire'. He explained that the true meaning of the metaphorical expression is 'I am burning with love'. Thus, it can be seen that this expression does not mean 'I am on fire with love' but rather a metaphor that means 'I am drunk with love'.

An explanation of the conceptual metaphor put forward by Lakoff \& Johnsen (2003) states that it is the result of mental construction based on the principle of analogy which involves the conceptualization of one element to another. These elements consist of two components, namely the source domain which is usually concrete in nature, such as things that are obtained in everyday life, and the target domain which is usually abstract in nature, thus indicating a transfer of concepts from one concept to another. For example, the expression 'Love is fire' can be explained that the word 'Fire' is included as the source domain and the word 'Love' being the target domain. Therefore, it can be concluded that the word love has similarities with the word fire. This means that the analogy of love can be burning, passionate, and can even go out like a fire. This analogy process is called the transfer of one concept to another.

It is clear that the use of metaphors in the language is very much influenced by the variety of each individual's cultural background. This is reinforced by arguments made by Kövecses (2000) which reveals that metaphors simply reflect cultural models., The impact of cultural background is closely related to language. Because language and culture are like two inseparable sides of a coin. Therefore, it can be seen that the language field is not something that can stand alone without being linked or combined with other fields. One example, as put forward by Sapir (in Baginda, 2012) that the journey of a language goes hand in hand with cultural history. The SapirWhorf hypothesis believes that there is a relationship between language, culture, and human thought. This theory is known as the theory of linguistic relativity initiated by Franz Boas (1858-1942), Edward Sapir (1884-1939), and Benyamin Lee Whorf (1897-1941). In Kramsch (2011) they claim that people speak differently because they think in different ways. They think in different ways because their language offers a way of expressing (meaning) the world around them in different ways. Based on this theory, it certainly fits the criteria for using metaphors in language.

The use of metaphors needs to be applied in language use because it adds a different impression o makes it easier for someone to understand. This is reinforced by Cameron's thinking (in Dorst, 2010) which revealed that when people talk to each other, they will often use metaphors broadly. In a speech, metaphor is a shifting dynamic phenomenon that spreads, connects, and disconnects with other minds and other speakers, starts and restart, 
develops through dynamic speech, expands, and changes. The evidence for the cultural influence of the metaphor is supported by Shore's view (in Cienki, 2007) which reveals that cultural models are constructed as mental representations in the same way as any mental models with the important exception that the internationalization of cultural models is based on more socially constrained experiences than in the case for idiosyncratic models. This means that the cultural model itself is based on socially constrained experiences. Thus, it is assumed that each person will relate the metaphorical analogy differently according to their respective experiences, cultures, and cognition. One example of a metaphorical expression given by Lakoff $\&$ Johnsen (2003) namely 'Time is money'. This expression can be explained with various meanings. It could mean 'you're wasting my time' or it could mean 'I don't have the time to give you'. Both of these meanings have negative meanings because the meaning of the word 'time' in western culture is indeed something that is considered very valuable.

Nowadays, the use of metaphors is not only found in the scope of literature, such as in poetry, novels, and films. The use of metaphors is often found in non-fiction fields, such as news discourse and articles. This is usually done by news writers or journalists to increase their creativity in processing words and also aims to attract readers' attention. several studies proved that the use of metaphor has indeed penetrated the scope of non-fiction such as discourse, newspapers, and others. This is under the research conducted by Nirmala et al. (2010), which shows that metaphorical expressions are often used in newspaper discourse, especially when it comes to political issues during the PILEG 2009 period. Then another study was carried out by Tawami \& Sari (2018) which also showed that conceptual metaphors were used again even in political rhetoric. Not only that, further research conducted by Haula \& Nur (2019) is still focused on the conceptualization of metaphors in newspapers. However, in this study, the newspaper under examination is an opinion rubric and examines the study of metaphors in terms of cognitive semantics. Therefore, it can be concluded that the use of metaphors in news media or letters has indeed been done a lot and deserves to be examined. Even the findings in the research of Poyungi et al., (2021) state that there are two types of modality metaphors used to convey the speaker's opinion on what he or she said. This shows that metaphor is very influential on the communication process. However, of course in this study, there will be significant differences. In this study, the newspapers studied were German media newspapers. Then it will be linked and compared with the translation in Indonesian. This is deemed necessary to find out the irregularities contained in the vocabulary under study, as well as to prove whether the vocabulary is a metaphor or not. In addition, this study will also answer the question of whether a metaphorical expression in German and Indonesian has the same or different meaning.

In writing articles, journalists assume that the choice of unusual words will make readers more curious about the content of the news. For 
example, news with the headline Pergulatan Prancis Melawan Islamisme in newspapers Deutsche Welle will have a more controversial meaning than simply Prancis Melawan Islamisme. From several exposures which have been mentioned above can raise a specific question, how can we understand the meaning of each metaphorical expression contained in various languages, if the use of metaphors is indeed influenced by culture? In German media newspapers. Of course, German and Indonesian cultures are very different, especially in terms of language. There are so many vocabularies in German that don't even have their equivalent in Indonesian. This is very difficult in the field of translation when you want to interpret a word that has the same meaning. As stated by Fauzi et al., (2021) that each culture has its own uniqueness and uniqueness. This is mostly caused by the fact that culture contains the identity or characteristics of a group of people who inhabit a certain area. Therefore, this research intends to compare every metaphorical meaning that is in the newspaper and relate it to the theory of linguistic relativity, so that it can be seen that the theory of linguistic relativity is acceptable or not in the use of conceptual metaphors.

\section{METHOD}

This study uses a qualitative descriptive analysis method, as stated by Sugiyono (2015) that the descriptive analysis method is used to analyze data by describing or describing the collected data as it is. The quotation means that the data will be analyzed through depiction or comparison according to the context of the sentence and its meaning. The sample selection in this study is used to select data sources, namely newspapers and metaphorical expressions contained in these newspapers. Then a 5-step metaphor analysis based on Steen's theory will be applied.

The step that needs to be done before implementing the 5-Step Method is to identify the meaning of each word related to the metaphor based on the dictionary. The dictionary used is KBBI (Kamus Besar Babasa Indonesia) and DUDEN (German dictionary). These two dictionaries are used to compare the meanings of words from two different languages, namely Indonesian and German. In this way, it will be clear whether or not there is a similarity in the meaning of each metaphor so that it can be continued in the 5-Step Analysis Method.

In this process, Steen (2011) states that this 5-Step Metaphor Analysis Method is to forge the relationships between metaphorical forms in text and speech along with the conceptual structure of metaphors as assumed in cognitive linguistics in the mapping of conceptual metaphors such as ARGUMENT IS WAR. This 5-Step Metaphor Analysis Method is:

1. Metaphor focus identification;

2. Metaphorical idea identification;

3. Non-literal comparison identification;

4. Non-literal analogy identification, and 
After the metaphor identification process is complete, it will be continued by comparing the results of each description of the meaning of each metaphor and relating it to the Sapir-Whorf theory (in Kramsch, 2011) which reveals the connection between language, culture, and human thoughts. This hypothesis is closely related to the structure of language, which when used continuously can affect the way a person thinks and behaves. So, by referring to this hypothesis, it is hoped that there will be a clear final result to see whether or not there is a difference in the meaning of each word related to the metaphor based on its description between German culture and Indonesian culture.

\section{FINDINGS AND DISCUSSION}

Based on the analysis process that has been carried out, identify metaphorical expressions in the newspaper Deutsche Welle published on 21 and 22 October 2020, it can be concluded that these expressions fall into the realm of conceptual metaphors. This is based on the use of the 5-step metaphor analysis method. Steen (2011) reveals that it is important to use this 5-Step Analysis Method to determine whether or not there is a deliberate metaphor. Therefore, the use of this 5-Step Metaphor identification is deemed suitable to be applied in the process of analyzing metaphorical expressions in a text to see clearly whether these expressions can be categorized as metaphorical expressions or not.

\section{Meaning Comparison of the Metaphorical Expressions}

In the process of identification of meanings, it is common to find various similarities in terms of meanings between Indonesian and German. For example, the word 'wrestling' in German has a broader meaning than in Indonesian, but this does not become an obstacle in concluding the meaning. If examined more fundamentally the word 'wrestling' in German has quite a lot of synonyms, so that it can be compared with the corresponding meaning of the word 'wrestling' in Indonesian. For example, in German, the word for 'wrestling' is der Kampf which means: major military conflict between opposing forces; violent controversies between opponents regarding their views, interests, goals; continuous striving to achieve or prevent something; and inner conflict, an inner struggle for something. While in the KBBI mentioned pergulatan has only two meanings, struggle and struggle with great effort. From this brief explanation, the conclusion is that the meaning of the word 'wrestling' is 'struggle'.

Although the explanation of the meaning of each word element in German always has a broader meaning than in Indonesian, it turns out that 
some Indonesian words sometimes do not exist in German. This is what causes a little confusion in the search for meaning. The word mengurita, for example, in KBBI means: tightly wrapped around something (such as the hands of an octopus); took root and spread everywhere. Whereas in German the word cannot be interpreted. It is very difficult to find a specific German equivalent of the word mengurita. Therefore, specifically for drawing conclusions the meaning of the word only refers to one perspective, namely according to Indonesian.

Table 1:

Meaning Comparison of Vocabulary Related to Metaphors

\begin{tabular}{|c|c|c|c|}
\hline Vocabulary & $\begin{array}{l}\text { Meaning in } \\
\text { Indonesian }\end{array}$ & $\begin{array}{c}\text { Meaning in } \\
\text { German language }\end{array}$ & $\begin{array}{l}\text { Drawing } \\
\text { Conclusion } \\
\text { Meaning }\end{array}$ \\
\hline $\begin{array}{l}\text { Pergulatan } \\
\text { der Kampf }\end{array}$ & $\begin{array}{l}\text { struggle, struggle with } \\
\text { great effort }\end{array}$ & $\begin{array}{l}\text { 1. major military conflicts } \\
\text { between enemy forces; } \\
\text { 2. violent controversies } \\
\text { between opponents } \\
\text { regarding their views, } \\
\text { interests, goals; } \\
\text { 3. continuous striving to } \\
\text { achieve or prevent } \\
\text { something; } \\
\text { 4.inner conflict, the inner } \\
\text { struggle for something }\end{array}$ & Struggle \\
\hline $\begin{array}{l}\text { Melawan } \\
\text { gegen }\end{array}$ & $\begin{array}{l}\text { 1. against; violate; } \\
\text { 2. compete cheaper } \\
\text { than others; } \\
\text { 3. serve; } \\
\text { 4. invite } \\
\text { 5. prevent, eliminate; } \\
\text { keep away; } \\
\text { 6. resistance } \\
\text { processes, methods, } \\
\text { efforts to prevent } \\
\text { (fend off, survive, and } \\
\text { so on) }\end{array}$ & $\begin{array}{l}\text { 1. shows contradictions; } \\
\text { 2. characterizes certain } \\
\text { [opposite] actions of } \\
\text { people, groups with each } \\
\text { other; } \\
\text { 3. show a reaction, approach } \\
\text { to someone, something, } \\
\text { opponent }\end{array}$ & Resistance \\
\hline $\begin{array}{l}\text { Hantu } \\
\text { der Geist }\end{array}$ & $\begin{array}{l}\text { 1. evil spirits (which } \\
\text { are thought to be } \\
\text { present in certain } \\
\text { places) }\end{array}$ & $\begin{array}{l}\text { 1. spiritual beings; } \\
\text { 2.ghost, ghost figure; } \\
\text { 3.terrifying creature [in } \\
\text { human form]; } \\
\text { 4. humans in terms of their } \\
\text { spiritual qualities; } \\
\text { 5.people who are } \\
\text { characterized by the } \\
\text { nature of a particular } \\
\text { activity or behavior }\end{array}$ & $\begin{array}{l}\text { Scary } \\
\text { creature }\end{array}$ \\
\hline
\end{tabular}




\begin{tabular}{|c|c|c|c|}
\hline $\begin{array}{l}\text { Aksi } \\
\text { die Aktion }\end{array}$ & $\begin{array}{l}\text { 1. movement; } \\
\text { 2.action; } \\
\text { 3.attitude or behavior } \\
\text { made up } \\
\end{array}$ & $\begin{array}{l}\text { 1.treatment [Joint planned], } \\
\text { measurement; } \\
\text { 2. act, be active }\end{array}$ & Action \\
\hline Menggurita & $\begin{array}{l}\text { 1.tightly wrapped } \\
\text { around something } \\
\text { (like octopus } \\
\text { hands); } \\
\text { 2.took root and } \\
\text { spread everywhere }\end{array}$ & - & Spread \\
\hline $\begin{array}{l}\text { Kebangkitan } \\
\text { die } \\
\text { Auferstehung }\end{array}$ & $\begin{array}{l}\text { 1.about rising from the } \\
\text { dead; } \\
\text { 2.wake up (from } \\
\text { sleep, sit) then } \\
\text { stand up; } \\
\text { 3. wake up (live) again; } \\
\text { 4. arise or arise }\end{array}$ & $\begin{array}{l}\text { 1.rise again, be reborn; } \\
\text { 2.come back }\end{array}$ & Arises \\
\hline $\begin{array}{l}\text { Mengakar } \\
\text { verwurzelt }\end{array}$ & $\begin{array}{l}\text { 1.be the root; } \\
\text { 2.resembling roots; } \\
\text { 3.deep or truly united } \\
\text { in the heart, mind, } \\
\text { and so on (about } \\
\text { teachings, customs, } \\
\text { and so on) }\end{array}$ & $\begin{array}{l}\text { 1. rooted in something (have } \\
\text { a strong mental } \\
\text { attachment to something: } \\
\text { he is deeply rooted in his } \\
\text { homeland, in tradition) }\end{array}$ & Deep \\
\hline $\begin{array}{l}\text { Masalah } \\
\text { das Problem }\end{array}$ & $\begin{array}{l}\text { 1.question; } \\
\text { 2.application; } \\
\text { 3.something that has } \\
\text { to be done (solved); } \\
\text { question; problem; } \\
\text { 4.the most } \\
\text { complicated }\end{array}$ & $\begin{array}{l}\text { 1. difficult [not completed] } \\
\text { tasks, difficult questions } \\
\text { to answer, complicated } \\
\text { questions, problems; } \\
\text { 2.trouble }\end{array}$ & Problem \\
\hline $\begin{array}{l}\text { Mempertajam } \\
\text { schärfen }\end{array}$ & $\begin{array}{l}\text { 1.looks fierce (view); } \\
\text { 2.scathing or harsh } \\
\text { (about words, } \\
\text { criticism, etc.); } \\
\text { 3. easy to grasp or } \\
\text { understand (about } \\
\text { reason, thoughts, } \\
\text { etc.); } \\
\text { 4.can easily injure or } \\
\text { hurt; } \\
\text { 5.more real, clear, and } \\
\text { so on; } \\
\text { 6.smart (about the } \\
\text { mind); } \\
\text { 7.make sharper }\end{array}$ & $\begin{array}{l}\text { 1. (by grinding or } \\
\text { sharpening) make clear, } \\
\text { sharp; } \\
\text { 2. improve and perfect its } \\
\text { function; } \\
\text { 3. trained, fix }\end{array}$ & $\begin{array}{l}\text { Make it } \\
\text { even more } \\
\text { real }\end{array}$ \\
\hline
\end{tabular}




\begin{tabular}{|c|c|c|c|}
\hline $\begin{array}{l}\text { Perdebatan } \\
\text { die Debatte }\end{array}$ & $\begin{array}{l}\text { 1.prebuttal; } \\
\text { 2.discussion and } \\
\text { exchange of } \\
\text { opinions on a } \\
\text { matter by giving } \\
\text { reasons to each } \\
\text { other's opinions }\end{array}$ & $\begin{array}{l}\text { 1. lively discussions, } \\
\text { arguments, disagreements; } \\
\text { 2. discussion on a subject in } \\
\text { Parliament }\end{array}$ & Dispute \\
\hline $\begin{array}{l}\text { Gerakan } \\
\text { die Bewegung }\end{array}$ & $\begin{array}{l}\text { 1.act or state of } \\
\text { motion (water, sea, } \\
\text { machinery); } \\
\text { 2.movements, } \\
\text { businesses, or } \\
\text { activities in the } \\
\text { social field (politics } \\
\text { and so on) }\end{array}$ & $\begin{array}{l}\text { 1.the politically significant } \\
\text { (intellectual or ideological) } \\
\text { joint effort of a large } \\
\text { group; } \\
\text { 2. more people coming } \\
\text { together to achieve } \\
\text { common [political] goals }\end{array}$ & Activities \\
\hline $\begin{array}{l}\text { Bawah Tanah } \\
\text { der Untergrund }\end{array}$ & $\begin{array}{l}\text { 1.in the ground; } \\
\text { 2. figuratively dark or } \\
\text { secret (about } \\
\text { movement and so } \\
\text { on) }\end{array}$ & $\begin{array}{l}\text { 1. social area outside the } \\
\text { established society, } \\
\text { legality; } \\
\text { 2. foundation, foundation }\end{array}$ & Secret \\
\hline $\begin{array}{l}\text { Konten } \\
\text { der Inbalt }\end{array}$ & $\begin{array}{l}\text { The information } \\
\text { available through } \\
\text { media or electronic } \\
\text { products }\end{array}$ & $\begin{array}{l}\text { 1. something that is } \\
\text { expressed in something, is } \\
\text { represented; } \\
\text { 2. something that fills } \\
\text { something up spiritually; } \\
\text { Spiritual content that gives } \\
\text { meaning }\end{array}$ & Information \\
\hline $\begin{array}{l}\text { Pembunuban } \\
\text { der Mord }\end{array}$ & $\begin{array}{l}\text { process, means, the } \\
\text { act of killing }\end{array}$ & $\begin{array}{l}\text { the deliberate murder of one } \\
\text { or more persons with low } \\
\text { motives }\end{array}$ & Murder \\
\hline $\begin{array}{l}\text { Darah } \\
\text { membeku } \\
\text { die } \\
\text { Blutgerinnung }\end{array}$ & $\begin{array}{l}\text { 1. figuratively has not } \\
\text { changed; (rigid); } \\
\text { static; } \\
\text { 2. figuratively do not } \\
\text { care about the } \\
\text { circumstances around } \\
\text { him; didn't react; } \\
\text { 3. figuratively scary } \\
\text { thing }\end{array}$ & $\begin{array}{l}\text { Blood clots in the veins } \\
\text { (after injury) }\end{array}$ & Scary \\
\hline $\begin{array}{l}\text { Wajab } \\
\text { das Gesicht }\end{array}$ & $\begin{array}{l}\text { 1. the front of the } \\
\text { head; facial features; } \\
\text { 2. figures (players and } \\
\text { so on); } \\
\text { 3. description, pattern }\end{array}$ & vision & Figure \\
\hline
\end{tabular}




\section{Metaphor Analysis Process 5 Steps Method}

Metaphor analysis using this method refers to the example of the analysis conducted by Steen et al. (2010). Various previous studies have also been conducted using the metaphor identification process of this method, some of which have been carried out by Beger (2011) of deliberate metaphorical analysis, Group (2007), Panther (2009) and Steen et al. (2010) has even done a thorough test. This method is suitable to forge relationships between metaphorical forms in text and speech along with the conceptual structure of metaphors as assumed in cognitive linguistics, where the mapping of conceptual metaphors such as Argument is war becomes Arguments < Weapons. The mapping is considered suitable and easy to conclude metaphorical expressions contained in the discourse text, especially in this study. Because it can facilitate the analysis process to conclude that the expressions in this text fall into the realm of conceptual metaphors. The following table shows an example of the results of analysis of metaphorical expressions using the 5-Step Method:

Table 2:

Metaphor Analysis of the 5 Step Method (G. Steen, 2011)

\begin{tabular}{|c|c|}
\hline Steps & Analysis \\
\hline Text: 1 & Pergulatan Prancis melawan Islamisme \\
\hline $\begin{array}{l}\text { 1. Identification of metaphor related } \\
\text { words }\end{array}$ & pergulatan \\
\hline $\begin{array}{l}\text { 2. Identification of metaphor related } \\
\text { propositions }\end{array}$ & $\begin{array}{l}\text { P1 }\left(\text { Prancis }_{\mathrm{s}} \text { melawan Islamisme }\right. \\
\text { pergulatan } \\
\mathrm{t}\end{array}$ \\
\hline $\begin{array}{l}\text { 3. Identification of open metaphorical } \\
\text { comparison }\end{array}$ & $\begin{array}{l}\text { SIM }\{F, x, y \\
{\left[F(\text { pergulatan })_{t}\right.} \\
\left.[\text { Prancis melawan Islamisme }(x, y)]_{s}\right\}\end{array}$ \\
\hline $\begin{array}{l}\text { 4. Identification of open metaphorical } \\
\text { comparison }\end{array}$ & $\begin{array}{l}\text { SIM } \\
{[\text { perjuangan (pergulatan) }]_{\mathrm{t}}} \\
\text { [ perlawanan (Prancis melawan } \\
\text { Islamisme) }]_{\mathrm{s}}\end{array}$ \\
\hline $\begin{array}{l}\text { 5. Identification of cross-domain } \\
\text { mapping }\end{array}$ & $\begin{array}{l}\text { TARGET }<\text { SOURCE DOMAIN } \\
\text { Perjuangan }<\text { Perlawanan } \\
\text { Pergulatan }<\text { Perlawanan } \\
\text { possible inferences : } \\
\text { ARGUMENTS }<\text { WEAPONS }\end{array}$ \\
\hline Text: 2 & Hantu Islam melancarkan aksi kekerasan \\
\hline $\begin{array}{l}\text { 1. Identification of metaphor related } \\
\text { words }\end{array}$ & Hantu Islam \\
\hline $\begin{array}{l}\text { 2. Identification of metaphor related } \\
\text { propositions }\end{array}$ & P1 ( aksi $_{\mathrm{s}}$ kekerasan $_{\mathrm{s}}$ hantu Islam ${ }_{\mathrm{t}}$ ) \\
\hline
\end{tabular}




\begin{tabular}{|c|c|}
\hline $\begin{array}{l}\text { 3. Identification of open metaphorical } \\
\text { comparison }\end{array}$ & $\begin{array}{l}\operatorname{SIM}\{F, x, y \\
{\left[F(\text { hantu Islam })_{\mathrm{t}}\right.} \\
\left.[\text { aksi kekerasan }(x, y)]_{\mathrm{s}}\right\}\end{array}$ \\
\hline $\begin{array}{l}\text { 4. Identification of open metaphorical } \\
\text { comparison }\end{array}$ & $\begin{array}{l}\text { SIM } \\
{[\text { makhluk menakutkan (hantu Islam) }]_{\mathrm{t}}} \\
{[\text { tindakan kekerasan (aksi kekerasan) } \mathrm{s}}\end{array}$ \\
\hline $\begin{array}{l}\text { 5. Identification of cross-domain } \\
\text { mapping }\end{array}$ & $\begin{array}{l}\text { TARGET < SOURCE DOMAIN } \\
\text { Makhluk menakutkan }<\text { Tindakan } \\
\text { kekerasan } \\
\text { Hantu Islam < Tindakan kekerasan } \\
\text { possible inferences : } \\
\text { ARGUMENTS < WEAPONS }\end{array}$ \\
\hline Text: 3 & $\begin{array}{l}\text { Semakin_menggurita menyusul } \\
\text { kebangkitan Islamic State. }\end{array}$ \\
\hline $\begin{array}{l}\text { 1. Identification of metaphor related } \\
\text { words }\end{array}$ & menggurita \\
\hline $\begin{array}{l}\text { 2. Identification of metaphor related } \\
\text { propositions }\end{array}$ & $\begin{array}{l}\text { P1 (kebangkitan } \text { Islamic State }_{\mathrm{s}} \\
\text { menggurita }_{\mathrm{t}} \text { ) }\end{array}$ \\
\hline $\begin{array}{l}\text { 3. Identification of open metaphorical } \\
\text { comparison }\end{array}$ & $\begin{array}{l}\operatorname{SIM}\{F, x, y \\
{\left[F(\text { menggurita })_{\mathrm{t}}\right.} \\
\left.[\text { kebangkitan Islamic State }(x, y)]_{\mathrm{s}}\right\}\end{array}$ \\
\hline $\begin{array}{l}\text { 4. Identification of open metaphorical } \\
\text { comparison }\end{array}$ & $\begin{array}{l}\text { SIM } \\
{[\text { menyebar (menggurita) }]_{\mathrm{t}}} \\
{[\text { timbul (kebangkitan) }]_{\mathrm{s}}}\end{array}$ \\
\hline $\begin{array}{l}\text { 5. Identification of cross-domain } \\
\text { mapping }\end{array}$ & $\begin{array}{l}\text { TARGET }<\text { SOURCE DOMAIN } \\
\text { Menyebar }<\text { Timbul } \\
\text { Menggurita }<\text { Timbul } \\
\text { possible inferences : } \\
\text { ARGUMENTS }<\text { WEAPONS }\end{array}$ \\
\hline Text: 4 & Masalahnya sudah mengakar \\
\hline $\begin{array}{l}\text { 1. Identification of metaphor related } \\
\text { words }\end{array}$ & mengakar \\
\hline $\begin{array}{l}\text { 2. Identification of metaphor related } \\
\text { propositions }\end{array}$ & P1 (masalahnya mengakar $_{t}$ ) \\
\hline $\begin{array}{l}\text { 3. Identification of open metaphorical } \\
\text { comparison }\end{array}$ & $\begin{array}{l}\operatorname{SIM}\{F, x, y \\
{\left[F(\text { mengakar })_{t}\right.} \\
\left.[\text { masalahnya }(x, y)]_{\mathrm{s}}\right\}\end{array}$ \\
\hline $\begin{array}{l}\text { 4. Identification of open metaphorical } \\
\text { comparison }\end{array}$ & $\begin{array}{l}\text { SIM } \\
{[\text { mendalam (mengakar) }]_{\mathrm{t}}} \\
{[\text { persoalan (masalahnya) }]_{\mathrm{s}}}\end{array}$ \\
\hline
\end{tabular}




\begin{tabular}{|c|c|}
\hline $\begin{array}{l}\text { 5. Identification of cross-domain } \\
\text { mapping }\end{array}$ & $\begin{array}{l}\text { TARGET }<\text { SOURCE DOMAIN } \\
\text { Mendalam }<\text { Persoalan } \\
\text { Mengakar }<\text { Persoalan } \\
\text { possible inferences : } \\
\text { ARGUMENTS }<\text { WEAPONS }\end{array}$ \\
\hline Text: 5 & $\begin{array}{l}\text { Ranah publik ikut mempertajam } \\
\text { perdebatan saat ini }\end{array}$ \\
\hline $\begin{array}{l}\text { 1. Identification of metaphor related } \\
\text { words }\end{array}$ & mempertajam \\
\hline $\begin{array}{l}\text { 2. Identification of metaphor related } \\
\text { propositions }\end{array}$ & P1 (perdebatan mempertajam $_{\mathrm{t}}$ ) \\
\hline $\begin{array}{l}\text { 3. Identification of open metaphorical } \\
\text { comparison }\end{array}$ & $\begin{array}{l}\operatorname{SIM}\{F, x, y \\
{\left[F(\text { mempertajam })_{t}\right.} \\
\left.[\text { perdebatan }(x, y)]_{\mathrm{s}}\right\}\end{array}$ \\
\hline $\begin{array}{l}\text { 4. Identification of open metaphorical } \\
\text { comparison }\end{array}$ & $\begin{array}{l}\text { SIM } \\
{[\text { membuat semakin nyata }} \\
(\text { mempertajam }]_{\mathrm{t}} \\
{[\text { perselisihan }(\text { perdebatan })]_{\mathrm{s}}}\end{array}$ \\
\hline $\begin{array}{l}\text { 5. Identification of cross-domain } \\
\text { mapping }\end{array}$ & $\begin{array}{l}\text { TARGET < SOURCE DOMAIN } \\
\text { Membuat semakin nyata }<\text { Perselisihan } \\
\text { Mempertajam }<\text { Perselisihan } \\
\text { possible inferences : } \\
\text { ARGUMENTS }<\text { WEAPONS }\end{array}$ \\
\hline Text: 6 & Gerakan bawah tanah kelompok salafi. \\
\hline $\begin{array}{l}\text { 1. Identification of metaphor related } \\
\text { words }\end{array}$ & bawah tanah \\
\hline $\begin{array}{l}\text { 2. Identification of metaphor related } \\
\text { propositions }\end{array}$ & $\begin{array}{l}\text { P1 (gerakan } \text { kelompok salafi }_{\mathrm{s}} \text { bawah } \\
\left.\operatorname{tanah}_{\mathrm{t}}\right)\end{array}$ \\
\hline $\begin{array}{l}\text { 3. Identification of open metaphorical } \\
\text { comparison }\end{array}$ & $\begin{array}{l}\text { SIM }\{F, x, y \\
{[F \text { (bawah tanah)t }} \\
\left.[\text { gerakan kelompok salafi }(x, y)]_{\mathrm{s}}\right\}\end{array}$ \\
\hline $\begin{array}{l}\text { 4. Identification of open metaphorical } \\
\text { comparison }\end{array}$ & $\begin{array}{l}\text { SIM } \\
{\left[\text { rahasia }(\text { bawah tanah) }]_{\mathrm{t}}\right.} \\
{[\text { kegiatan }(\text { gerakan })]_{\mathrm{s}}}\end{array}$ \\
\hline $\begin{array}{l}\text { 5. Identification of cross-domain } \\
\text { mapping }\end{array}$ & $\begin{array}{l}\text { TARGET }<\text { SOURCE DOMAIN } \\
\text { Rahasia }<\text { Kegaiatan } \\
\text { Bawah tanah }<\text { Kegaiatan } \\
\text { possible inferences : } \\
\text { ARGUMENTS }<\text { WEAPONS }\end{array}$ \\
\hline Text: 7 & $\begin{array}{l}\text { Konten pembunuban bisa membuat darah } \\
\text { membeku }\end{array}$ \\
\hline $\begin{array}{l}\text { 1. Identification of metaphor related } \\
\text { words }\end{array}$ & darah membeku \\
\hline
\end{tabular}




\begin{tabular}{|c|c|}
\hline $\begin{array}{l}\text { 2. Identification of metaphor related } \\
\text { propositions }\end{array}$ & $\begin{array}{l}\text { P1 (konten pembunuhan } \text { darah } \\
\left.\text { membeku }_{t}\right)\end{array}$ \\
\hline $\begin{array}{l}\text { 3. Identification of open metaphorical } \\
\text { comparison }\end{array}$ & $\begin{array}{l}\text { SIM }\{F, x, y \\
{\left[F(\text { darah membeku })_{\mathrm{t}}\right.} \\
\left.[\text { konten pembunuhan }(x, y)]_{\mathrm{s}}\right\}\end{array}$ \\
\hline $\begin{array}{l}\text { 4. Identification of open metaphorical } \\
\text { comparison }\end{array}$ & $\begin{array}{l}\text { SIM } \\
{[\text { menakutkan (darah membeku) }]_{\mathrm{t}}} \\
{[\text { informasi pembunuhan }(\text { konten }} \\
\text { pembunuhan) }]_{\mathrm{s}}\end{array}$ \\
\hline $\begin{array}{l}\text { 5. Identification of cross-domain } \\
\text { mapping }\end{array}$ & $\begin{array}{l}\text { TARGET < SOURCE DOMAIN } \\
\text { Menakutkan }<\text { Informasi pembunuhan } \\
\text { Darah membeku }<\text { Informasi } \\
\text { pembunuhan } \\
\text { possible inferences : } \\
\text { ARGUMENTS }<\text { WEAPONS }\end{array}$ \\
\hline Text: 8 & Sammuel Patty menjadi wajah republik \\
\hline $\begin{array}{l}\text { 1. Identification of metaphor related } \\
\text { words }\end{array}$ & wajah republik \\
\hline $\begin{array}{l}\text { 2. Identification of metaphor related } \\
\text { propositions }\end{array}$ & P1 (Sammuel Pattys wajah republikt \\
\hline $\begin{array}{l}\text { 3. Identification of open metaphorical } \\
\text { comparison }\end{array}$ & $\begin{array}{l}\text { SIM }\{F, x, y \\
{[F \text { (wajah republik) })_{\mathrm{t}}} \\
\left.[\text { Sammuel Patty }(x, y)]_{\mathrm{s}}\right\}\end{array}$ \\
\hline $\begin{array}{l}\text { 4. Identification of open metaphorical } \\
\text { comparison }\end{array}$ & $\begin{array}{l}\text { SIM } \\
{[\text { tokoh negara (wajah republik) }]_{\mathrm{t}}} \\
{[\text { Sammuel Patty (Sammuel Patty) }]_{\mathrm{s}}}\end{array}$ \\
\hline $\begin{array}{l}\text { 5. Identification of cross-domain } \\
\text { mapping }\end{array}$ & $\begin{array}{l}\text { TARGET }<\text { SOURCE DOMAIN } \\
\text { Tokoh negara }<\text { Sammuel Patty } \\
\text { Wajah republik }<\text { Sammuel Patty } \\
\text { possible inferences : } \\
\text { ARGUMENTS }<\text { WEAPONS }\end{array}$ \\
\hline
\end{tabular}

From the results of the metaphorical analysis above, it can be seen that all the bolded words in these expressions are a form of metaphor. In each sentence, there is a source domain and a target domain, which when juxtaposed with mapping ARGUMENTS < WEAPONS the position is appropriate and does not experience a change in the overall meaning, so it can be said that this conceptual metaphor proof analysis is successful. This is in line with the theory Lakoff \& Johnsen (2003) which reveals that metaphors are the result of mental constructions based on analogy principles that involve the conceptualization of one element to another. It is clear that the analogy process is made to express a word in other words but it can still be understood in context. It's different if each of these words is released from the context, maybe the essence of the sentence will be incomprehensible at all. 
However, one of the weaknesses of this 5-Step Analysis Method is the mapping stage. If only seen from the mapping Argument is war becomes ARGUMENTS < WEAPONS, then maybe there will be some cases of metaphorical expressions which do not fit the mapping and will even add to the confusion. Therefore, it is one of the studies that has been conducted by Krenmayr (in Steen et al., 2010) notes that the difficulty of deciding conceptual metaphors for these non-specific examples is a common problem. Then he decided to use the Succeeding is winning mapping which more specifically became SUCCEEDING IN A BID IS WINNING A COMPETITION, arguing that the interest in mapping is appropriate for the conceptual structure of 'winning'. However, mapping can be based on the objective of the analysis itself, so this is a weakness in the process of selecting the appropriate mapping.

\section{Relationship between Language and Culture based on the Perspective of Linguistic Relativity}

There is a theory which states that communication in language cannot be separated from the interference of cultural aspects. This theory is known as the theory of language (linguistics) relativity or better known as the SapirWhorf hypothesis. Basically, culture becomes the foundation of life and people's perspective. Everyone judges from a cultural perspective. There is no personal discretion for individual choices (Silalahi, 2011). In his research, Whorf found that language actually affects the world view of its users. This is illustrated in the following scheme:

Picture 1:

Whorf's Perspective on World View (Silalahi, 2011)

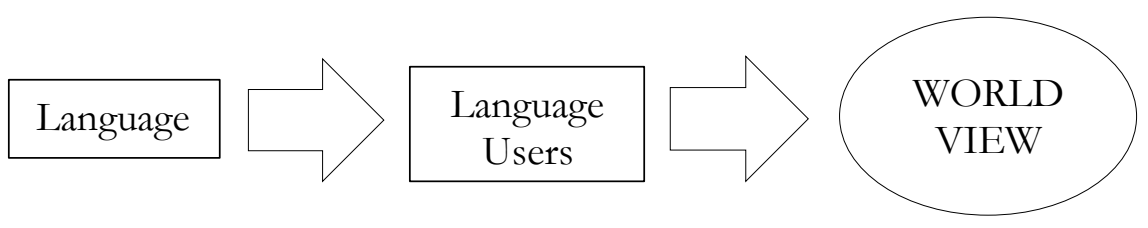

Arrow (A) describes the relationship between language and its users, which can build or generate views of each of the world itself (arrow B). For example, there is a linguistic phenomenon that involves color naming or color terms. There are two sides to the debate about the naming of the colors, namely universalists and relativists. The universalist side claims that the biology of all humans is the same, thus the development of color terminology has absolute universal limits. Meanwhile, the relativist side emphasizes that the variability of the term color across linguistically (from language to language) shows a more specific phenomenon in culture. Since color denotes both biological and linguistic aspects, color has become the focus of the study of the relationship between language and thought mixed with cultural aspects. 
Another research conducted by Kay \& Regier (2006) concluded that there are universal limitations on the naming of colors, but at the same time, differences in color naming across languages lead to differences in color cognition and/or perception. From these studies, it can be concluded that the color in each environment determines the language used by individuals from that group in daily conversation. Thus, the naming of color categories depends partly on language, and more so on objects that stand out in their environment. In other words, for colors to be distinguished, they must already exist in an individual or cultural group environment. In addition, another simple example can be taken from the word padi in the perspective of the Indonesian people which already has a different meaning when compared to the perspective of the Germans. In KBBI the word padi itself means plants that produce rice; grain and grain. Whereas in German the word padi (rice plants) can only be translated into der Reis which means nasi (cooked rice). Whereas from the Indonesian perspective it is clear that the meaning of padi and nasi is different and has different functions. However, in German padi and nasi are the same word, although they may have different meanings. This happens because in German culture there is no need for a vocabulary related to padi. Unlike the Indonesians, for Indonesians, padi is a riceproducing plant that can be processed to nasi as a staple food, while for the Germans this is not the case. Therefore, the use of a specific name for an object will indeed vary in each environment. This is of course influenced by each existing culture.

Likewise with the use of metaphorical expressions in two languages and different perspectives, if this is linked to the Sapir-Whorf hypothesis as previously described, there will be a clear difference that the perspective of metaphorical expressions in the perspective of German and Indonesian culture will be different. This is also emphasized by Hadiati (2017) in his research which explains that the contribution the speaker makes in a conversation depends not only on how he can produce an utterance but also on how the other person receives and interprets it. So, this can be proven by the existence of different vocabulary placements. For example, metaphorical expressions in two different languages are as follows:

- $\quad$ semakin menggurita menyusul kebangkitan Islamic State (Indonesian)

- $\quad$ zunehmend mit dem Aufstieg der Terrororganisation "Islamischer Staat"

(German language)

One analogy of the word menggurita in Indonesian means 'spreading'. Whereas in German there is no analogy to the word menggurita and it is replaced by placing the word zunebmend which has the meaning 'increase'. If we look deeper into the two meanings, between 'spreading' and 'increasing' it has a similar meaning but with a different vocabulary placement. This is consistent with the Sapir-Whorf hypothesis where culture determines different thoughts and perspectives. Therefore, the theory of linguistic relativity can be said to be acceptable to the use of conceptual metaphors. 


\section{CONCLUSION}

Nowadays, the use of metaphors is not only found in the scope of literature, such as in poetry, novels, and films. The use of metaphors is often found in non-fiction fields, such as news discourse texts and articles. This is usually done by news writers or journalists to increase their creativity in processing words and also aims to attract the readers' attention. Journalists think that choosing unusual words will make readers more curious about the content of the news.

The use of metaphors in the language is very much influenced by the variety of individual cultures. The impact of culture is closely related to language. Because language and culture are like two inseparable sides of a coin. Therefore, it can be seen that the language field is not something that can stand alone without being linked or combined with other fields.

To know clearly the meaning of each metaphorical expression in the discourse text, the 5-Step Metaphor Analysis Method can be used. This method is deemed suitable to clearly observe whether these expressions can be categorized as metaphorical expressions or not. It's just that this method has a weakness in mapping, which can lead to confusion in the process of selecting an appropriate mapping. However, the convenience of using this $5-$ step method is that you can clearly observe the analogy of each metaphorical word contained in the text. From the results of the metaphor analysis in this study, it can be concluded that the existence of the theory of linguistic relativity is acceptable in making conceptual metaphors, where culture determines one's thoughts and point of view, especially in analyzing metaphors.

\section{REFERENCES}

Beger, A. (2011). Deliberate metaphors? An exploration of the choice and functions of metaphors in US-American college lectures. Metaphorikde.

Cienki, A. (2007). Metaphor and Corpus Linguistics - Review. Metaphor and Symbol, 22(March 2015), 195-200.

Deignan, A. (2016). From linguistic to conceptual metaphors. The Routledge Handbook of Metaphor and Language, 102-116. https://doi.org/10.4324/9781315672953

Dorst, A. G., \& Pasma, T. (2010). The Cambridge Handbook of Metaphor and Thought, edited by Raymond W. Gibbs. Metaphor and Symbol. https://doi.org/10.1080/10926488.2011.535420

Duden.de. (2018). Rechtschreibung, Bedeutung, Definition, Herkunft. In Duden. 
Fauzi, M. I., Khasanah, N., \& Pavita, M. D. A. (2021). The Concept of Color Metaphor In Sundanese: A Semantic Cognitive Study. Lensa: Kajian Kebahasaan, Kesusastraan, Dan Budaya, 11(1), 33. https://doi.org/10.26714/lensa.11.1.2021.33-41

Group, P. (2007). MIP: A Method for Identifying Metaphorically Used Words in Discourse. Metaphor and Symbol. https://doi.org/10.1207/s15327868ms2201_1

Hadiati, C. (n.d.). Linguistic Devices Reflecting Women's s Inferiority in Tohari's Ronggeng Dukub Paruk. 7(1), 114-123.

Haula, B., \& Nur, T. (2019). Konseptualisasi Metafora Dalam Rubrik Opini Kompas: Kajian Semantik Kognitif. RETORIKA: Jurnal Bahasa, Sastra, Dan Pengajarannya, 12(1), 25. https://doi.org/10.26858/retorika.v12i1.7375

Ii, B. A. B., \& Teoretis, L. (2006). Putrasulung Baginda, 2012 Pemberitaan Islam Dan Terorisme Dalam Media Jerman: Sebuah Analisis Sosiokognitif Universitas Pendidikan Indonesia | repository.upi.edu 6. 6-25.

Kay, P., \& Regier, T. (2006). Language thought and color: Recent developments. In Trends in Cognitive Sciences. https://doi.org/10.1016/j.tics.2005.12.007

Kbbi. (2016). KBBI Daring. In Badan Pengembangan dan Pembinaan Bahasa, Kementerian Pendidikan dan Kebudayaan Republik Indonesi.

Kövecses, Z. (2000). Metaphor and Emotion: Language, Culture, and Body in Human Feeling. Studies in Emotion and Social Interaction.

Kramsch, C. (2011). Language and culture. In The Routledge Handbook of Applied Linguistics. https://doi.org/10.4324/9780203835654

Lakoff, George; Johnsen, M. (2003). George Lakoff and Mark Johnson ( 2003 ) Metaphors we live by. London: The University of Chicago Press. Noter om layout: Innholdsfortegnelse I Word: In Journal of Philosophy.

Lakoff, G., \& Johnsen, M. (2003). Afterword. In Metaphors, We Live By.

Linguistic Relativity: Edward Sapir's Perspective on Language, Culture, and Cognition Ronald Maraden Parlindungan Silalahi Bunda Mulia University. (n.d.). 1(1), 75-90.

Nirmala, D., Ilmu, F., \& Universitas, B. (2010). Komponen Makna Ungkapan Metaforis Dalam Pileg 2009 Dalam Wacana Surat Pembaca Di Harian Suara Merdeka. PAROLE: Journal of Linguistics and Education, 1(0), 13 36. https://doi.org/10.14710/parole.v1i0.808 
Panther, K. U. (2009). Finding metaphor in grammar and usage: A methodological analysis of theory and research. Gerard J. Steen, John Benjamins, Amsterdam/Philadelphia, 2007, 430 pp., EUR 110.00/USD 165.00. Journal of Pragmatics. https://doi.org/10.1016/j.pragma.2009.01.005

Pentopikalan, K., \& Minangkabau, B. (2018). Hipotesis Sapir-Whorf , Pentopikalan, Dan Kesantunan Berbahasa Dalam Zul Amri Refnaldi. January 2010.

Poyungi, Y. S., Nababan, M., \& Santosa, R. (2021). Translation Techniques of Modality Metaphor in Anne of Green Gables. Lensa: Kajian Kebahasaan, Kesusastraan, Dan Budaya, 11(1), 68. https://doi.org/10.26714/lensa.11.1.2021.68-79

Steen, G. (2011). From three dimensions to five steps: The value of deliberate metaphor. Metaphorik.De, 2011(21), 83-110.

Steen, G. J., Dorst, A. G., Berenike Herrmann, J., Kaal, A. A., Krennmayr, T., \& Pasma, T. (2010). A Method for Linguistic Metaphor Identification: From MIP to MIPVU (Converging Evidence in Language and Communication Research).

Sugiyono. (2015). Metode Penelitian Pendidikan. Bandung. In Metode Penelitian Pendidikan (Pendekatan Kuantitatif, Kualitatif, dan R\&D).

Tawami, T., \& Sari, R. P. (2018). Metafora konseptual pada wacana retorika politik. Jurnal AKR AB JUARA, 3(4), 59-69. 